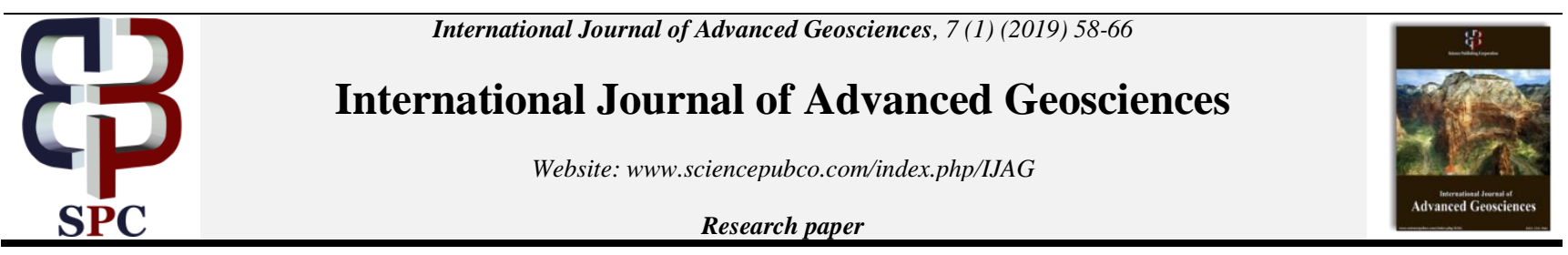

\title{
Depositional Environment and facies analysis of Useni- 1, Niger Delta Basin, using well logs, core data
}

\author{
G. O Aigbadon ${ }^{1 *}$, E. O. Akpunonu ', S. O. Agunloye ${ }^{1}$, A. Ocheli ${ }^{2}$, O. O .Akakaru ${ }^{2}$ \\ ${ }^{I}$ Wesley University of Science and Technology, Ondo. Ondo State \\ ${ }^{2}$ Nnamdi Azikiwe University, Awka Anambra State \\ *Corresponding author E-mail: godwin.aigbadon@yahoo.com
}

\begin{abstract}
This study was carried out integrating well logs and core to build reservoir model for the Useni-1 oil field. Core data and well logs were used to evaluate the petrophysical characteristics of the reservoirs. The paleodepositional environment was deduce from the wells and cores data. The depositional facies model showed highly permeable channels where the wells where positioned. The environments identified that the fluvial channel facies with highly permeable zones constituted the reservoirs. Four reservoirs were mapped at depth range of $8000 \mathrm{ft}$ to $8400 \mathrm{ft}$ with thicknesses varying from $20 \mathrm{ft}$ to $400 \mathrm{ft}$. Petrophysical results showed that porosity of the reservoirs varied from $12 \%$ to $28 \%$; permeability from $145.70 \mathrm{md}$ to $454.70 \mathrm{md}$; water saturation from $21.65 \%$ to $54.50 \%$ and hydrocarbon saturation from $45.50 \%$ to $78.50 \%$. Core data and the gamma ray log trends with right boxcar trend indicate fluvial point bar and tidal channel fills in the lower delta plain setting. By-passed hydrocarbons were identified in low resistivity pay sands D1, D2 at depth of $7800-78100 \mathrm{ft}$ in the field.
\end{abstract}

Keywords: Depositional environments; Well data; Core data.

\section{Introduction}

The velocity of the waves varies in different lithologic units. Core and well log data provide detailed information and good understanding of the subsurface geology. The core and well log data is used to identify where structures and lithologic units of geologic interest can be inferred. It is a good tool for subsurface stratigraphic analysis. The logs give detailed information on the reservoir rocks, their thicknesses and characteristics. They provide excellent vertical resolution of the reservoir rocks. A good understanding of reservoir characteristics, petrophysical parameters, thickness and lateral extent are important factors in quantifying producible hydrocarbon pools (Schlumberger, 1989). These petrophysical parameters serve as inputs for reservoir volumetric estimation (Edward, 1990). Hydrocarbon in the Niger Delta Basin is produced from sandstones and unconsolidated sands which are predominant in the Agbada Formation. It is necessary to delineate the hydrocarbon reservoirs and evaluate them because they are the zones of commercial interest for hydrocarbon exploitations (Adewoye et al., 2013). The lateral variation in reservoir thickness is strongly controlled by growth faults with increased thickness towards the fault in the down-thrown block (Weber and Daukoru, 1975). In order to evaluate producibility of a field, there is need to properly and adequately characterized and evaluate reservoirs and their depositional facies. The types of depositional facies will determine the volume and types of hydrocarbon resource and evaluate reservoir production performance.

The Objective of this research work is to evaluate the depositional environment and predict reservoir performances using well logs and core data. 


\section{The Niger Delta Basin}

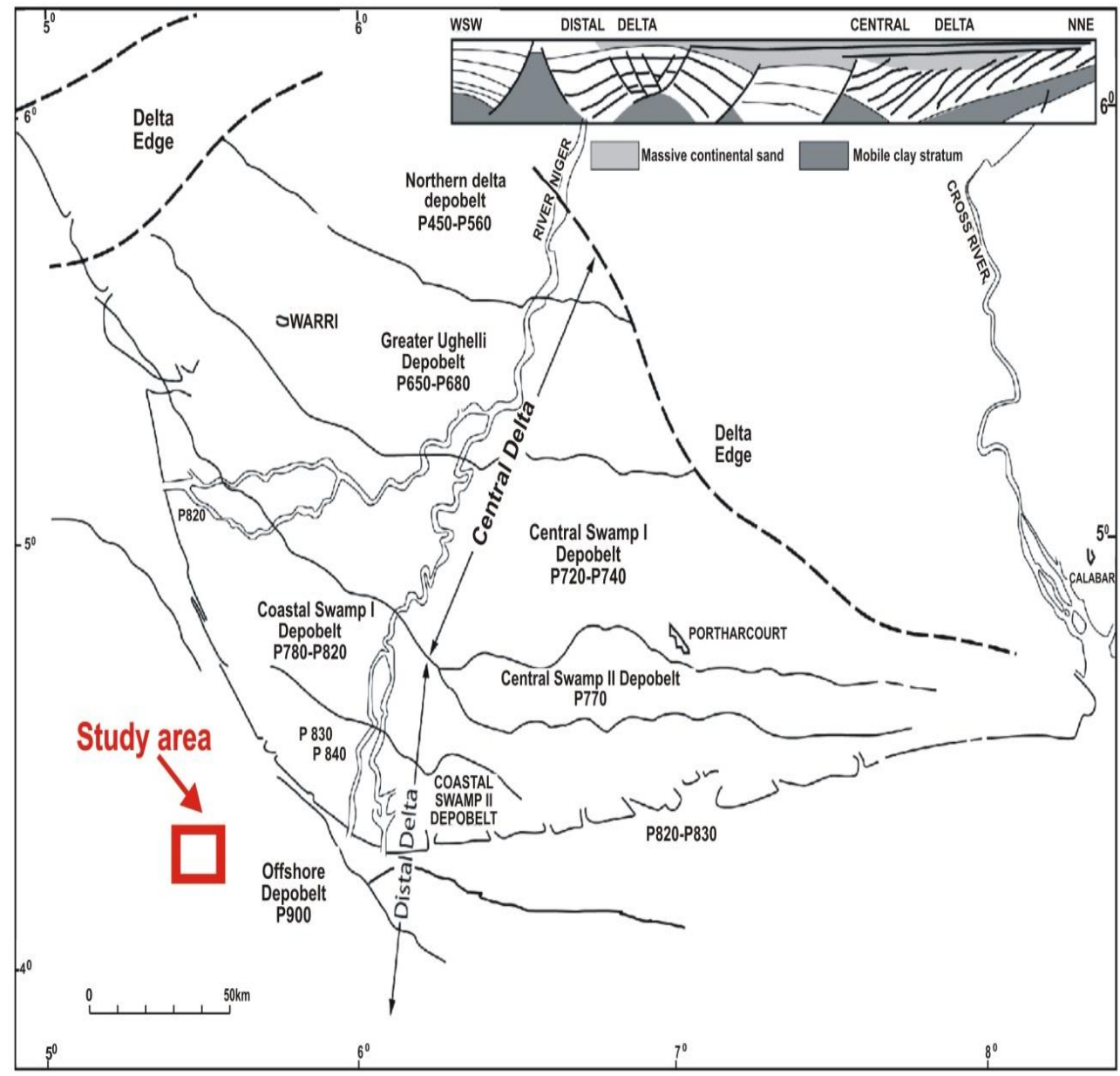

Fig. 1: Study Area Recognized in the Niger Delta Province (Weber, 1971).

The Cenozoic Niger Delta is situated at the intersection of the Benue Trough and the South Atlantic Ocean where a triple junction developed during the separation of the continents of South America and Africa in the late Jurassic (Whiteman, 1982). Subsidence of the African continental margin and cooling of the newly created oceanic lithosphere followed this separation in early Cretaceous times. Marine sedimentation took place in the Benue Trough and the Anambra Basin from mid-Cretaceous onwards. The Niger Delta (Fig.1) started to evolve in early Tertiary times when clastic river input increased (Doust and Omatsola, 1990). Knox and Omatsola (1989) stated that on the west, it is separated from the Dahomey (Benin) basin by the Okitipupa basement high, and on the east it is bounded by the Cameroun volcanic line. Its northern margin transects several older (Cretaceous) tectonic elements - the Anambra basin, Abakaliki uplift, Afikpo syncline, and Calabar Flank (Fig. 2). The evolution of the delta is controlled by pre- and synsedimentary tectonics as described in (Evamy et al., 1978; Ejedawe 1981; Knox and Omatsola, 1989). The tectonic framework of the continental margin along the West Coast of equatorial Africa is controlled by Cretaceous fracture zones expressed as trenches and ridges in the deep Atlantic. The fracture zone ridges (Fig.2) subdivide the margin into individual basins and in Nigeria, form the boundary faults of the Cretaceous Benue-Abakaliki trough which cuts far into the West African shield. 


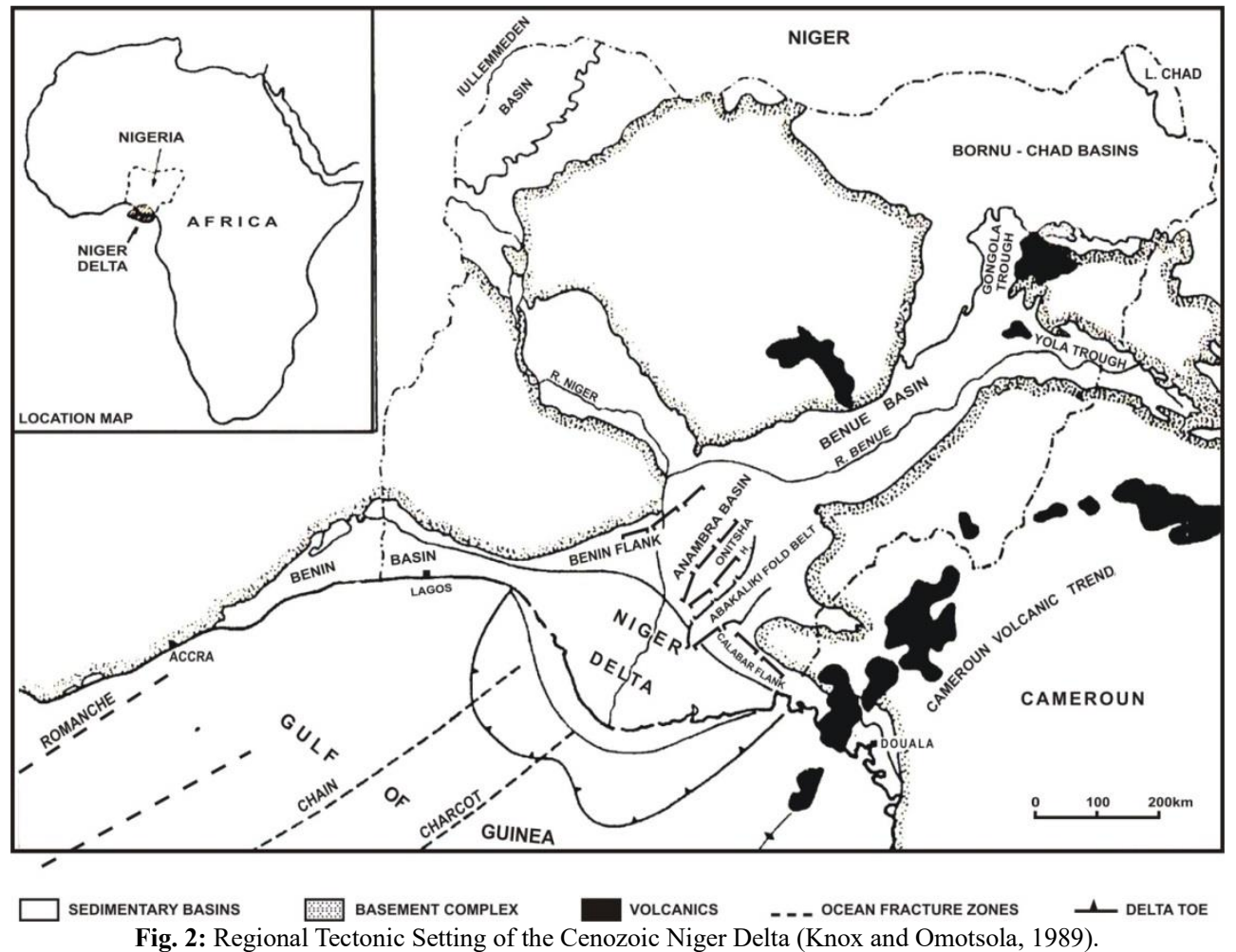

\subsection{Lithostratigraghic units of the Niger Delta Basin}

Three lithostratigrahic units have been recognized in the Niger Delta Basin (Short and Stauble, 1967 ; Weber and Daukoru, 1975; Doust and Omatsola, 1990). These are the Akata Formation, the Agbada Formation and the Benin Formation with respect to their ages. (Figs.3)

\subsubsection{The Akata Formation}

This represents the marine prodelta facies, comprising mainly of shales with occasional turbidite sandstones and siltstones. The age ranges from Paleocene in the proximal part of the delta to recent in the distal offshore (Doust and Omatsola, 1990). The approximate thickness range from $600 \mathrm{~m}-6000 \mathrm{~m}$. The formation consists of dark grey uniform shales in the lower part and sandy or silty shales part (Fig.3). The Akata shale is lagerly under compacted (ie. over pressured) in much of the delta. It is characterized by uniform shale development as evident in electric logs (Weber, 1971).

\subsubsection{The Agbada Formation}

The Agbada Formation overlies the Akata Formation. It consists of unconsolidated to slightly consolidated parallic siliciclastic sequence of sandstones. The structural elevation of the Agbada Formation fluctuates widely throughout the delta because of synsedimentary diapirism largely within the Akata Shale and subsequent growth faults. The oldest deposit of the Agbada Formation are of Eocene age in the Northern Depobelt. The formation consist of cyclic coarsening upward regressive sequences resulting from distributary channel migration and abandonment. This rhythmic sequence explain the multi- reservoir nature of most Nigeria oil and gas fields. The coarsening upward sequences are composed of alternating shales, sands, sandstone and silt which include delta front and lower delta plain deposits (Weber, 1971).

\subsubsection{The Benin Formation}

The Benin Formation is the youngest lithostratigraphic unit in the Niger Delta. It age is from Oligocene to recent. It consist of continental sands which are partly unconsolidated, thin shales, lignite streaks and coal. The sands and gravels of the Benin Formation were deposited as point bars by braided stream and as channels on natural levees while the finer sediments were laid down in back swamps and oxbows (Weber, 1971). To date no commercial accumulation of oil and gas has been found within the formation (Weber, 1971). It has a thickness of about $2000 \mathrm{~m}$ (Fig.3). 


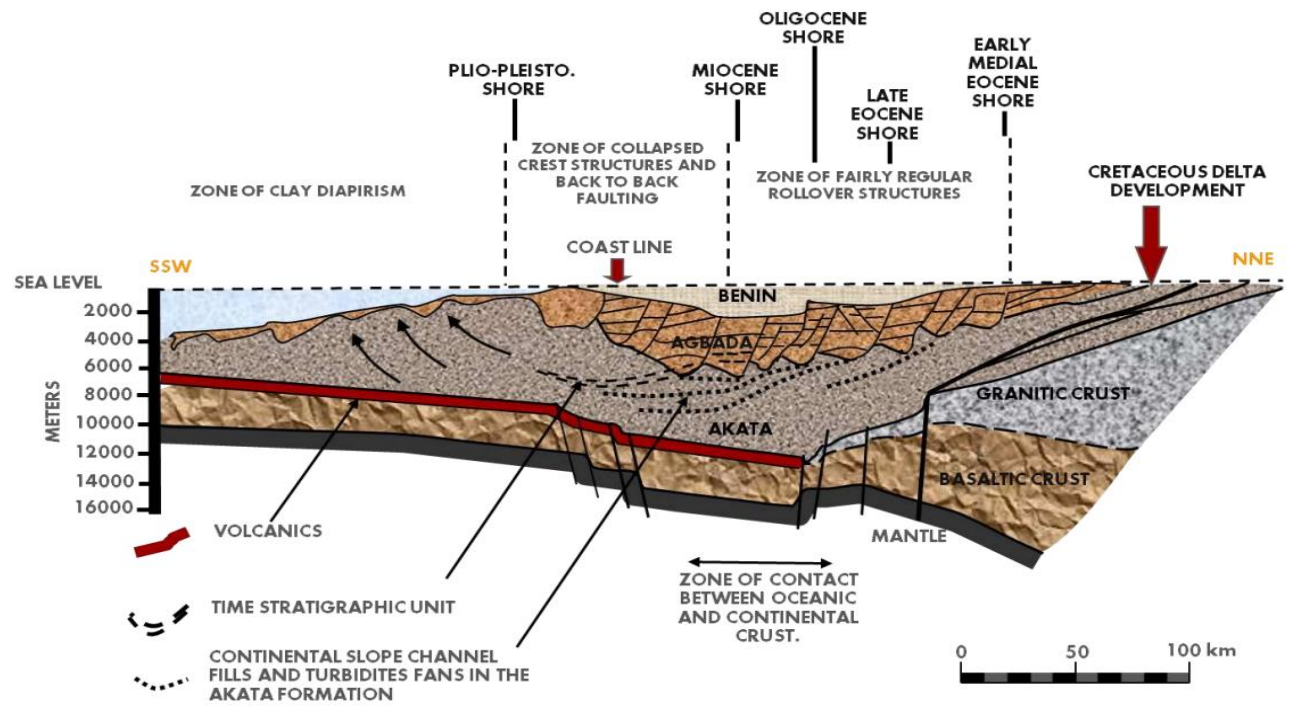

Fig. 3: Generalized Dip Section of the Niger Delta Basin (Doust and Omotsola, 1990).

\section{Materials and Method}

\subsection{Materials}

The data for this research comprises suites of geophysical wire-line logs, core data for four wells. The core and the gamma ray well logs were integrated for interpretation of depositional environment. This data was provided by Shell Petroleum Development Company (SPDC), Port Harcourt, Nigeria by the permission of Department of Petroleum Resources, Nigeria.

\subsection{Methodology}

The method of analysis involved delineation of lithologies, identification of facies and correlation of lithologies by log signatures. The integration of well logs and core data were used for identification of electrofacies as well as paleo-environmental reconstruction. Quality check was done on the well logs data to avoid pitfalls in their interpretation before being imported into the interactive Petrel workstation. The Gamma ray log which is a radioactive log recognizes low radioactive count in Sand zones and high gamma ray readings/counts in shaley zones because shale contain high radioactive materials. Reservoirs correlations were done based on recognition pattern of the gamma ray log at various depths. High gamma ray kick to the right depicts shale and low gamma reading or kick towards the lift depict sand. Depositional facies were identified based on the logs characteristic shapes. The paleo-environmental reconstruction was made based on the correlation analysis of the log motifs with the core data according (Cant 1992; Shell 1982).

\section{Result and discussion}

\subsection{Correlation in the wells}

The well correlation panel show the tops and bases of the reservoirs B1, B2, B3, B4, C1, C2, C3 in well 1-4 range from 8200ft -8350ft $(2500 \mathrm{~m}-2530 \mathrm{~m})$ respectively in Useni- 1 oil wells . The analysis of Gamma Ray (GR) shows that the overall lithology is an alternating sequence of sands and shales in Useni wells 1-4 (Fig.4).

The correlation and analysis of the all the well section revealed that sand B1,B2,B3,B4,C1,C2,C3 units extends laterally throughout the wells, while sand D1 and D2 exist as separates sand bodies due to faulting. The shale layers were observed to increase with depth along with a corresponding decrease in sand layers. This pattern in the Niger Delta indicates transition from Agbada Formation to Akata Formation. 


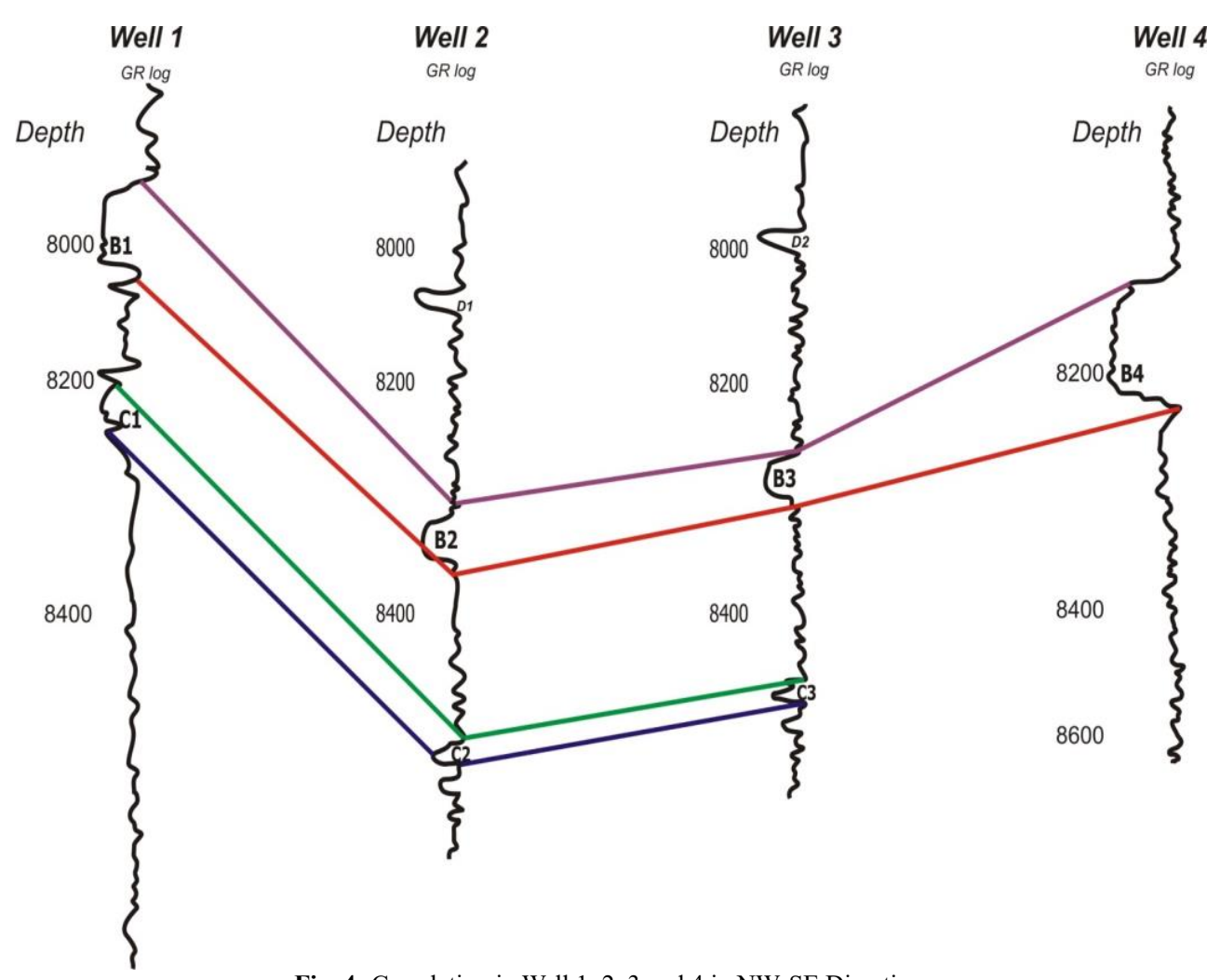

Fig. 4: Correlation in Well 1, 2, 3 and 4 in NW-SE Direction.

FUNMER

GR AND SP PROFILES

BEI
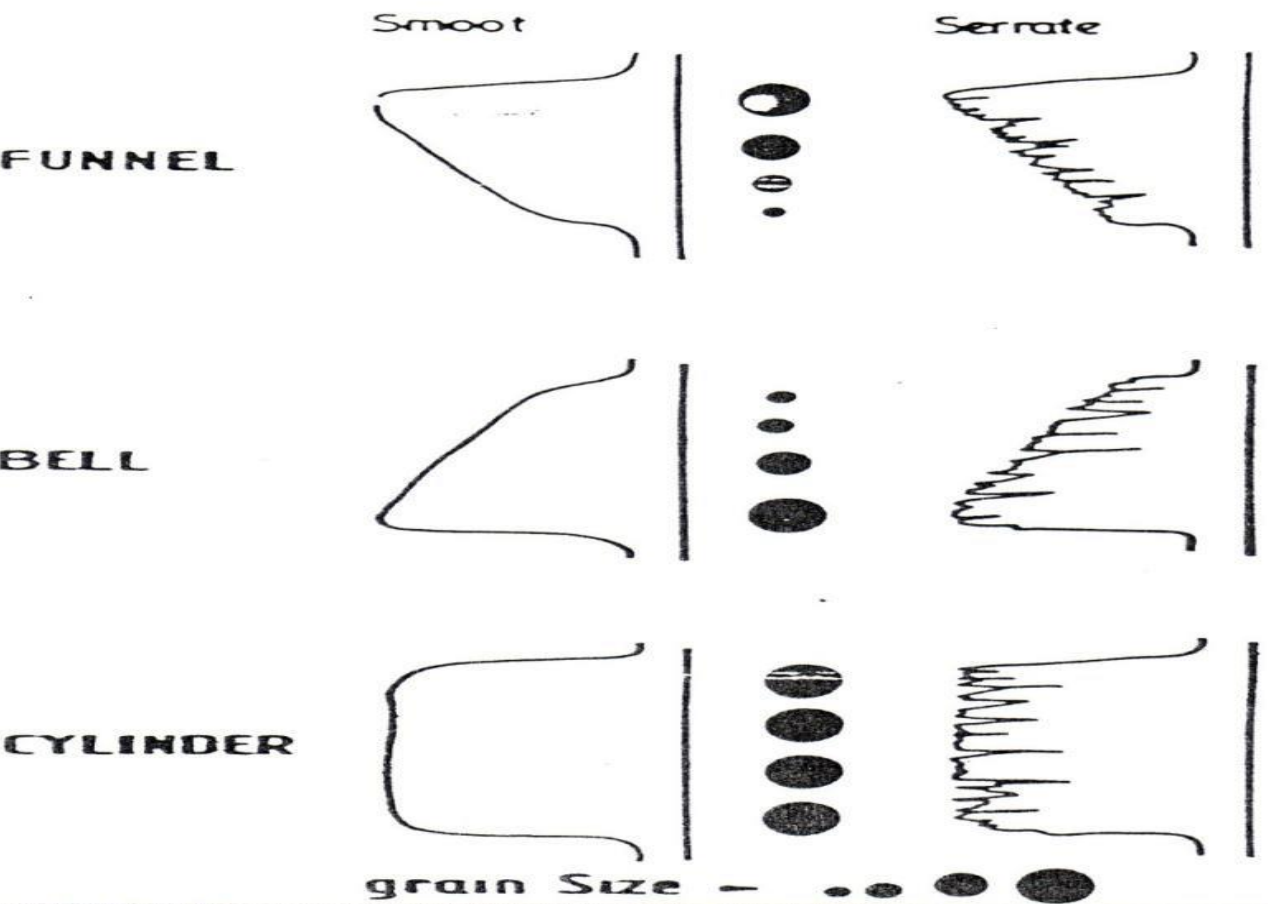

Fig. 5: Gamma Ray and SP Log Profiles Showing the Basic Shapes of Facies (After Shell, 1982). 


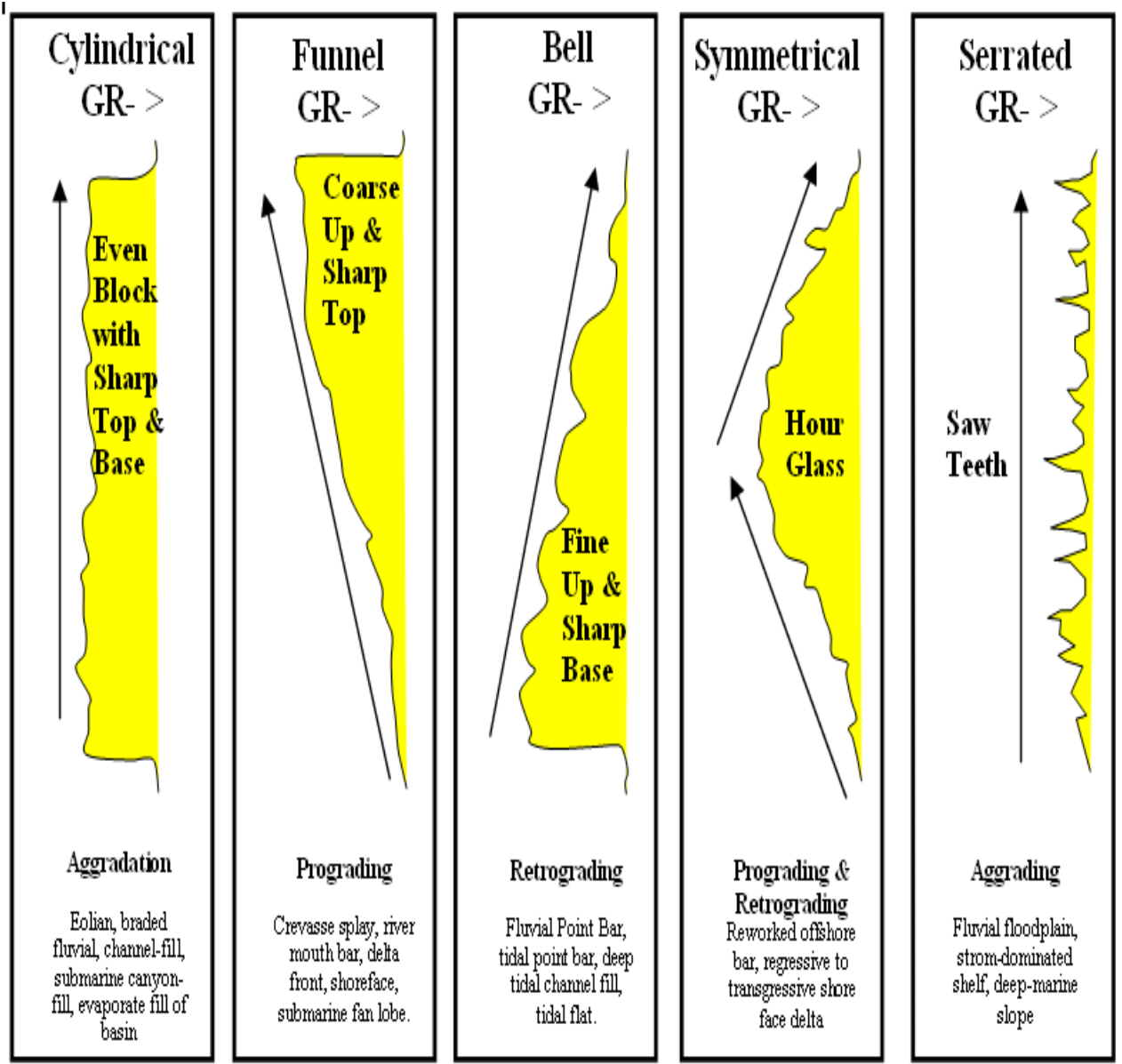

Fig. 6: Direct Correlation between Facies and A Variety of Other Log Shapes Relating to Sedimentological Relationship by Can’t (1992).

\subsection{Descriptions of the cores in well $1,2,4$}

The cores data provided for reservoir intervals in the three wells (Fig.7a-c) were studied and described from top to bottom below:

For well 1

Lithofacies for reservoir B1: Bioturbated cross bedded sandstones: Dominantly medium-fine-grained, moderately sorted light-Brown sandstones with dark colour. The upper part is characterized by moderately to well sorted sandstone.

For well 2

Lithofacies for reservoir B2: Medium coarse sandstone with shale lamination at the top.

Reservoir B2: Characterized by cross bedded fine to medium sandstone, with minor amount of shale parting and the Bioturbation decreases upward.

Well 4

Lithofacies for reservoir B4: Biotubated sandstone, characterized by moderately to well sorted sandstone. It is also characterized by cross bedding. 


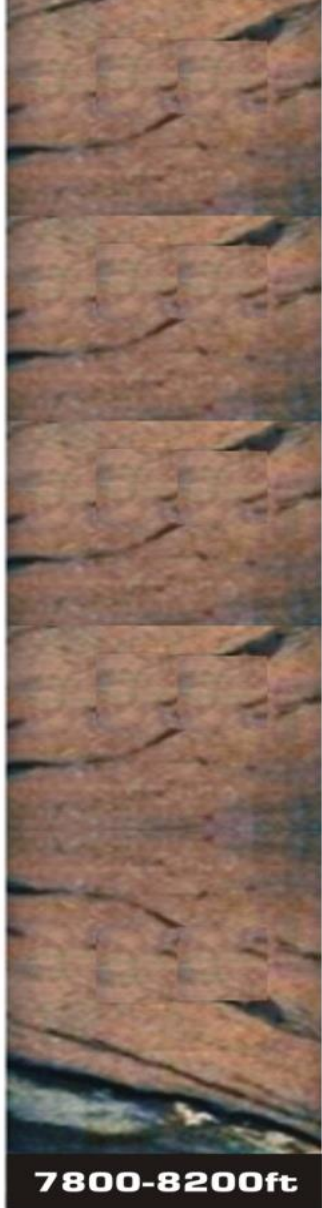

Well 1

Fig. 7: A) Core Log for Well 1

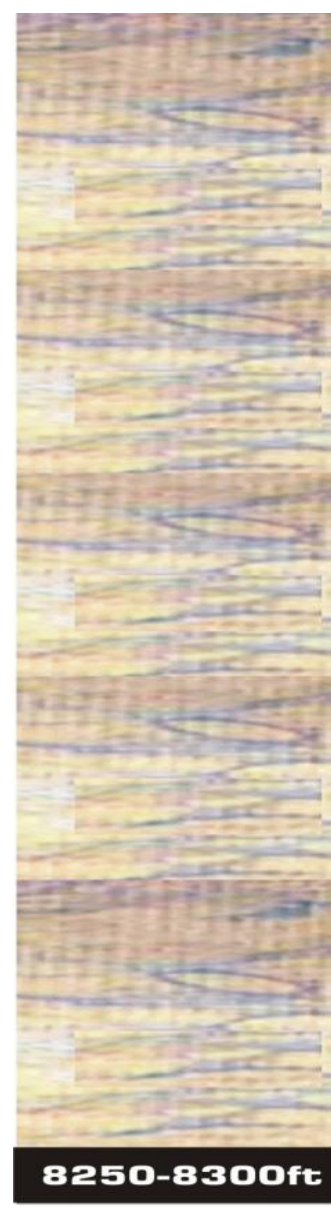

Well 2

Fig. 7: B) Core Log for Well 2

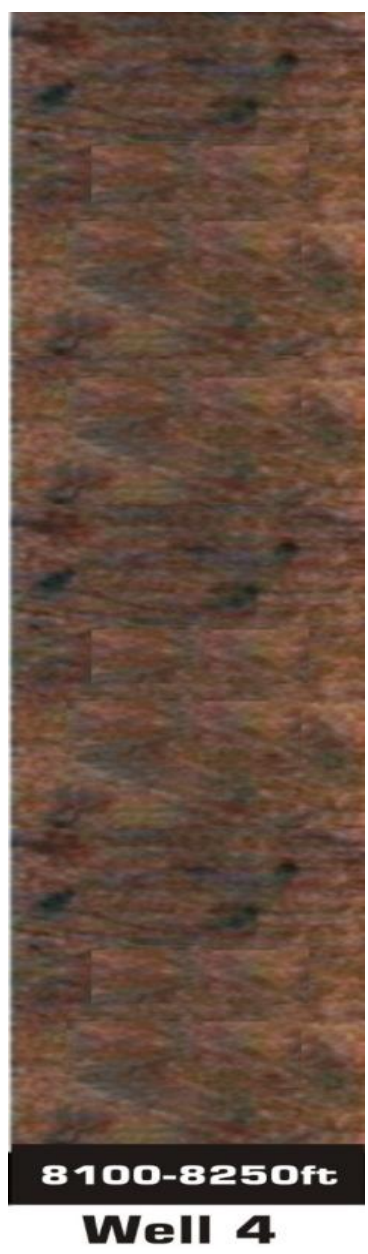

Fig. 7: C) Core Log for Well 4.

\subsection{Depositional environment and lithofacies from gamma ray log and core data}

Detailed description of facies from well logs and characteristitics of core lithology, textures, sedimentary structures that were dorminant during time of deposition were integrated for the interpretation of the depositional environment in the field.

Log Facies and Depositional Environment for well 1

Reservoir interval of $8000 \mathrm{ft}-8400 \mathrm{ft}(2500-2550 \mathrm{~m})$ in well 1 (Fig.7a.), the gamma ray log motif depicts a blocky car box trend. The environment can be classify as a distributary channel fills.

Reservoir interval of 8250- 8400ft (2500m- 2550) in well 1 from gamma ray log motif display a blocky trend. The core for reservoir $\mathrm{C} 1$ shows fine to medium grained sand bodies with very thin lamination of shales. Also, from the gamma ray log motif (Bush, 1975, Cant, 1992 ) and the core depicts a distributary channel fill.

Depositional Environment for Well 2

Reservoir interval 8250- 8300ft (2500- 2520m) depict blocky box car from the gamma ray log motif. This shows that the grains are almost equally distributed. The core shows that the sandstone reservoirs is characterized by medium to coarse sandstones with cross bedding. It depicts tidal channel sand.

Depositional Environment Interpretation for Well 4

Cyliderical Pattern (blocky) in Well 4

Reservoir A3 at depth interval of 8150- 8350ft (2470- 2530m) depicts a blocky left box car within thin lamination of shale at the base. The gamma ray log shows that grain are equally distributed (Fig.7c). The core shows that the sandstone is light brown with laminated shale at the base. It depicts a tidal channel environment (Cant, 1992 and Bush, 1975).

\subsection{Discussion of the depositional environment and its facies}

Using integrated data set of wireline logs, cores; four depositional facies were recognized as channel sands, tidal and distributary channels sands and flood plain. The gamma ray log motifs and cores were used to establish the lithology characteristics. The observed sequence in the wells located in the channels, consists of sand bodies with intercalation of sand and shale bodies indicating that logging started between the basal part of the Benin and the Agbada Formations (Fig.4). This stratigraphic sequence is typical of Agbada Formation in the Niger Delta, which is the productive zone based on the Wire line log motif and the depositional model. The depositional model have basic facies types that were delineated that corresponds to the gamma ray log motifs; they are tidal channel, flood plain, distributary mouth bar facies (Figs. 4, 5,6,7a-7c). These facies types are deposited in different depositional environments. Depositional environments are characterized by the facies types they contain. The depositional system in the Useni-1 field is classify as deltaic-fluvial environment based on the log motif and depositional facies model (Cant, 1992; Shell, 1982). The channel sand deposits in reservoir B1, B2, B3, B4 are classified as fluvial to deltaic settings and this is the characteristics of Agbada Formation where channels serve as reservoirs. The Fluviatile channel which is a subdivision of the deltaic-fluvial environment commonly consists of well sorted reservoirs 
B1, B2, B3, B4 and C3 in wells 1-4 located at the channels (Figs.4 \& 7a-c ) are thus the reservoirs that store much of the hydrocarbon in the field. The meandering system are responsible for distributing sediments within the field and are characterized by point bars deposits.

\subsection{Petrophysical analysis results}

Table 1: Petrophysical Results for Useni Wells

\begin{tabular}{|c|c|c|c|c|c|c|c|c|c|c|c|c|}
\hline Reservoirs & $\begin{array}{l}\text { Depth } \\
\text { (ft) }\end{array}$ & $\begin{array}{l}\text { Depth } \\
(\mathrm{m})\end{array}$ & $\begin{array}{l}\text { Gross } \\
\text { Sand }\end{array}$ & $\begin{array}{l}\text { Net Pay Sand (h) } \\
(\mathrm{m})\end{array}$ & $\begin{array}{l}\text { Shale Vol. } \\
\left(\mathrm{V}_{\mathrm{sh}}\right)\end{array}$ & $\begin{array}{l}\text { Net to Gross } \\
\text { (NTG) }\end{array}$ & Contact & $\begin{array}{l}\varnothing \\
(\%)\end{array}$ & $\mathrm{K}(\mathrm{md})$ & $\begin{array}{l}\mathrm{S}_{\mathrm{wa}} \\
(\%)\end{array}$ & $\begin{array}{l}\mathrm{S}_{\mathrm{h}} \\
(\%)\end{array}$ & Remarks \\
\hline D1 & $\begin{array}{l}7800- \\
7900\end{array}$ & $\begin{array}{l}2363- \\
2393\end{array}$ & 30.00 & 15.00 & 0.355 & 0.51 & & 0.14 & 145.70 & 0.461 & 0.529 & OIL \\
\hline D2 & $\begin{array}{l}8000- \\
8100\end{array}$ & $\begin{array}{l}2424- \\
2454\end{array}$ & 30.00 & 16.70 & 0.400 & 0.53 & GOC & 0.14 & 125.70 & 0.455 & 0.545 & GAS \\
\hline B & $\begin{array}{l}8000- \\
8350\end{array}$ & $\begin{array}{l}2424- \\
2530\end{array}$ & 106.30 & 75.30 & 0.053 & 0.71 & & 0.28 & 354.70 & 0.201 & 0.799 & OIL \\
\hline
\end{tabular}

\subsection{Effective porosity and core porosity values in the wells}

The effective porosity contain the producible amount of hydrocarbon in the wells. The effective porosity values range from 14-28\% and these porosities cut-off are good enough to support hydrocarbon production in the wells (David, 2002). The yellow area depicts highly porous areas (Table 1). The shale contents range from 0.033- 0.048 and is not high enough to hinder production of hydrocarbon from reservoirs B1, B2, B3, B4, C1, C2, C3, in the wells. The shale content estimated at the bypassed zone reservoirs of D1, D2 ranges 0.3550.400 in the wells and such will support production in the field.

Table 2: Estimated Petrophysical Results Showing Porosity and Saturations in the Wells

\begin{tabular}{|c|c|c|c|c|c|c|}
\hline Reservoirs & NTG & $(\varnothing \mathrm{e})$ & $\mathrm{S}_{\mathrm{wa}}$ & $\mathrm{S}_{\mathrm{h}}$ & $S_{\text {wirr }}$ from $(\varnothing c)$ & $\mathrm{S}_{\text {wirr }}$ from $(\varnothing \mathrm{T})$ \\
\hline D1 & 0.50 & 14.00 & 0.461 & 0.539 & 0.482 & 0.350 \\
\hline D2 & 0.58 & 14.00 & 0.455 & 0.545 & 0.462 & 0.360 \\
\hline B & 0.71 & 28.00 & 0.210 & 0.899 & 0.322 & 0.340 \\
\hline $\mathrm{C}$ & 0.48 & 16.00 & 0.422 & 0.578 & 0.532 & 0.330 \\
\hline
\end{tabular}

Water saturation values range from $20.10 \%-51.80 \%$ in reservoirs D1, D2, B, C in the wells. The water saturation estimated at the by passed zone sands of D1, D2 ranges $0.422-0.461 \%$ in the wells and such will support production in the field. After the detailed evaluation of prospects and re-evaluation of the wells the percentage of hydrocarbon saturation in the wells ranges from $57.80 \%-89.90 \%$ in reservoirs B, C in the wells. The hydrocarbon saturation estimated at the bypassed reservoirs D1, D2 range from 53.90-54.50\%.

The porosity barriers such as lenticular bedding and biotubation in (reservoir B, C in well 1and 2) which hinder the production rate and subsequent decline in the field was address from the depositional facies interpretation using cores and well log. The effective porosity was estimated by calculating the volume of shale from the total porosity of affected reservoirs B1,B2,B3,B4 and after estimation, the reservoirs effective porosities have improve to the range of $14-28 \%$, depicting fair to very good reservoirs (Table 2). The effective porosity contain the producible hydrocarbon zone (the net pay sand). Reservoir B is a barrier bar with effective porosity of 14-18\% indicate a good reservoir and hydrocarbon production can go on after re-evaluation of the wells, due to increase in the quality of effective porosity in the well.

The fine particle migration, bioturbation, shale drapes which act as permeability barriers associated with the reservoirs B1,B2,B3,B4, CI,C2,C3 in the field have been evaluated and minimized by improving on the quality of Net to Gross (NTG) ratio of the reservoir by dividing net reservoir sand to the gross reservoir. The NTG (oil zone) reflects the quality of reservoir. NTG $(0.48-0.71)$ and effective porosity values of (14-28\%) which contain the producible hydrocarbon in the reservoirs.

The micro porosity in the authigenic clay resulted to high apparent water saturation. The irreducible water saturation has reduce drastically which is one of the major problem in the field which result to decline in the yield of hydrocarbon production over the years from the producing wells in the field. This was achievable when correction of shale/clay effects were done on the affected reservoirs (B2, $\mathrm{C} 2$ ) on both on the well logs and cores. The clay bound water that was locked in the reservoirs (B2, C2) as a result poor architecture network of the reservoirs were removed. The estimated water saturation values range from (0.201-0.461) from the electric log estimated at interval of $8000 \mathrm{ft}-8400 \mathrm{ft}(2500-2532 \mathrm{~m})$. The high porosity and permeability cut show that reservoirs $(\mathrm{B} 2$, C2) we produce more hydrocarbon without producing water in the field. 


\begin{tabular}{|l|l|l|l|}
\hline Percentage Porosity (\%) & Qualitative Description & Average K, Value (md) & Qualitative Description \\
\hline $\mathbf{0 - 5}$ & Negligible & $5-10$ & Poor to fair \\
\hline $5-10$ & Poor & $15-50$ & Moderate \\
\hline $15-20$ & Good & $50-250$ & Good \\
\hline $20-30$ & Very Good & $250-1000$ & Very Good \\
\hline 30 & Excellent & 1000 & Excellent \\
\hline
\end{tabular}

\section{Conclusion}

The well and core data were integrated in this research to predict reservoir performance and improve reservoir quality at mapped horizons. The integrated core - well log approach is a pointer to environments of deposition in the field. The core well log analysis was also, used to characterized reservoirs in terms of geometry, porosity, permeability and reservoir architecture units. The core, well data analyses were used to interprete and reconstruct the environment of deposition in the field.

From our calculations, the water saturation values in the wells are not high, indicating that the major reservoir B, C, will produce mainly oil and gas without water.

\section{Recommendation}

1) I recommend 3-D and 4-D Study to identify new prospects and broader view of the study area.

\section{References}

[1] Amigun J. O. and. Bakare, N. O. (2013). Reservoir evaluation of "Danna" field Niger Delta using petrophysical analysis and 3-D seismic interpretation, 2 (55): 119-127.

[2] Amigun, J.O. and Odole, O.A. (2013). Petrophysical properties evaluation for reservoir characterisation of Seyi oil field (Niger-Delta). International Journal of Innovation and Applied Studies, 3 (3): 756-773.

[3] Avbovbo, A.A. (1978). Tertiary lithostratigraphy of Niger Delta. (62): 293-300. https://doi.org/10.1306/C1EA482E-16C9-11D7$8645000102 \mathrm{C} 1865 \mathrm{D}$.

[4] Beck, R.H. and Lehner, P. (1975). Oceans, new frontier in exploration. Association of American Petroleum Geologist Bulletin, (69) P.253.

[5] Bush, D.A. (1975). Influence of growth fault on sedimentation and prospect evaluation. The Association of American Petroleum Geologist Bulletin, 3 (59): 414-419. https://doi.org/10.1306/83D91C68-16C7-11D7-8645000102C1865D.

[6] Burke, K. (1972). Long shore drift, submarine canyons and submarine fans in development of Niger Delta. Association of American Petroleum Geologist Bulletin, (56): 1975-1983. https://doi.org/10.1306/819A41A2-16C5-11D7-8645000102C1865D.

[7] Cant, D.J. (1992). Subsurface facies analysis. Facies models: Response to sea level change. Geological Association of Canada. ISBN: 0919216498, 409.

[8] Doust, H. and Omatsola, M. E. (1990). Divergent passive margin basins. Association of American Petroleum Geologist Memoir (48): $201-238$.

[9] Edwards, J.D. and Santogrossi, P.A. (1990). Summary and Conclusions, in, Edwards, J.D. and Santogrossi, P.A. ed., Divergent/passive Margin Basins, Tulsa, American Association of Petroleum Geologists. 239-248.

[10] Ejedawe, J.R. and Okoh, S.U. (1981). Prediction of optimal depth of petroleum occurrence in Niger Delta Basin. Oil and Gas Journal, (79): 190204.

[11] Ekweozor, C.M. and Daukoru, E.M. (1984). Petroleum source beds evaluation of the tertiary Niger Delta. Association of American Petroleum Geologist Bulletin, (68):390-394. https://doi.org/10.1306/AD460A30-16F7-11D7-8645000102C1865D.

[12] Etu-Efeotor, J.O, (1997). Fundamentals of petroleum geology. Published by Paragraphics (an imprint of Jeson services). Port Harcourt, Nigeria. 146.

[13] Evamy, D.D., Haremeboure, J. Kamierling, W.A. Knaap, W.A. Molly and Rowland, P.H. (1978). Hydrocarbon Habitats of Tertiary Niger Delta, Association of American Petroleum Geologist Bulletin, (62):1-39. https://doi.org/10.1306/C1EA47ED-16C9-11D7-8645000102C1865D.

[14] Schlumberger (1989). Log Interpretation, Principles and Application: Schlumberger Wireline and Testing, Houston, Texas, United State of American. 21-89

[15] Short, K.C. and Stauble, A.J. (1967). Outline of geology of Niger Delta. Association ofAmerican Petroleum Geologist Bulletin, (51): 761-779. https://doi.org/10.1306/5D25C0CF-16C1-11D7-8645000102C1865D.

[16] Weber, K.J. (1971). Sedimentological aspects of oil fields in the Niger Delta; Geological Magazine, (50): .554-576.

[17] Weber, K.J. and Daukoru, E.M. (1975). Petroleum geology of Niger Delta. $9^{\text {th }}$ World Petroleum Congress, (2): 209-221.

[18] Whiteman, A.J. (1 '982). Nigeria: It petroleum geology, resources and potential. London, Graham and Trothman. 1:166. 